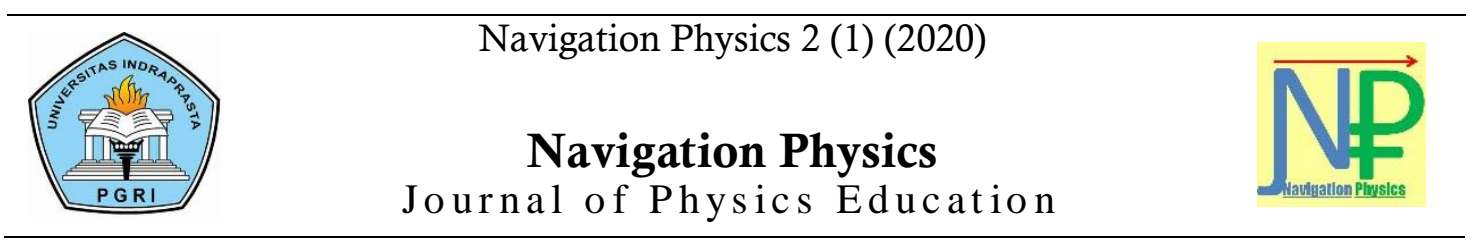

\title{
Pengaruh Metode Pembelajaran Inquiry Pictorial Riddle Terhadap Hasil Belajar Fisika Pada Sekolah Menengah Atas Negeri 85 Jakarta
}

\author{
Purwono Subagiyadi ${ }^{1^{*}}$, Neng Nenden Mulyaningsih ${ }^{2}$, Yoga Budi Bhakti ${ }^{3}$ \\ ${ }^{1}$ Sekolah Menengah Atas Negeri 85 Jakarta \\ ${ }^{2,3}$ Universitas Indraprasta PGRI \\ *E-mail: subagiyadi@gmail.com
}

\begin{tabular}{ll}
\hline Info Artikel & Abstract \\
\hline $\begin{array}{l}\text { Sejarah Artikel: } \\
\text { Diterima April } 2020 \\
\text { Disetujui Mei } 2020 \\
\text { Dipublikasikan Juni } 2020\end{array}$ & $\begin{array}{l}\text { Many factors influence the outcome of learning physics. One factor is } \\
\text { considered to be very important is the learning methods and early skills of }\end{array}$ \\
& $\begin{array}{l}\text { learners. Then this research aims to know the influence of the method of } \\
\text { enquiries pictorial Riddle and Inquiry learning method of learning results } \\
\text { of physics by controlling the initial ability of learners in class X IPA SMAN }\end{array}$ \\
\hline Keywords: & 85 Jakarta. The research methods used are experimental methods with \\
Inquiry Pictorial Riddle, Hasil Belajar & ANAKOVA analysis. The samples used were students of the X IPA class \\
Fisika & as many as 72 students spread in X IPA Class 1 and X IPA 2. The research \\
& $\begin{array}{l}\text { Data used to test hypotheses comes from the daily value document of the } \\
\text { results of physics learning outcomes at Law Newton. The instruments used } \\
\text { in the test have passed validity tests, reliability, difficulty levels, and } \\
\text { differentiation power. From the results of the study came the conclusion } \\
\text { that by controlling/controlling the influence of the original ability, there } \\
\text { are significant differences in physics learning outcomes among learners } \\
\text { who use the Methods enquiries Pictorial riddle }\left(\mathrm{F}_{\text {count }}<\mathrm{f}_{\text {table }}=0.88<3.28\right) \\
\text { and Learning method of inquiry }\left(\mathrm{F}_{\text {count }}<\mathrm{f}_{\text {table }}=0.65<3.28\right) .\end{array}$ \\
\hline
\end{tabular}

How to Cite: Subagiyadi, P., Mulyaningsih, N.N., \& Bhakti, Y.B (2020). Pengaruh Metode Pembelajaran Inquiry Pictorial Riddle Terhadap Hasil Belajar Fisika Pada Sekolah Menengah Atas Negeri 85 Jakarta. Navigation Physics, 2 (1): 41-46.

\section{PENDAHULUAN}

Sekolah merupakan pendidikan formal yang merupakanwadah untuk mencetak generasi-generasi penerus bangsa. Pendidikan di sekolah diwujudkan melalui berbagai mata pelajaran yang diterima peserta didik. Sekolah mempunyai tugas untuk mengembangkan dan menumbuhkan pengetahuan aspek kognitif, psikomotor, dan afektif. Selain itu sekolah mempunyai tujuan membentuk pribadi anak supaya menjadi manusia, warga masyarakat, dan warga negara yang baik.

Fisika merupakan salah satu ilmu pengetahuan alam yang membahas mengenai fenomena alam. Fisika yang merupakan salah satu bagian dari mata pelajaran Ilmu Pengetahuan Alam (IPA), dipelajari pada jenjang pendidikan dasar hingga pendidikan tinggi. Dalam kehidupan sehari-hari fisika juga banyak dimanfaatkan prinsip kerjanya, seperti pesawat sederhana, rangkaian listrik, mesin pendingin dan sebagainya. Hal ini menunjukan bahwa fisika sangat berperan bagi perkembangan ilmu pengetahuan dan teknologi.

Kondisi belajar di SMA Negeri 85 Jakarta yang menerapkan Kurikulum 2013 melibatkan peserta didik dalam belajar dan hasil belajar (ranah kognitif, afektif, dan psikomotorik) yang dicapai, diukur dengan berbagai cara seperti melalui proses kerja, hasil kerja, penampilan, rekaman dan lain-lain. Selain itu penilaian menekankan pada proses dan hasil belajar. Melihat kenyataan di SMA Negeri 85 Jakarta rerata hasil belajar Fisika yang dicapai peserta didik dalam penilaian harian pada KD Hukum Newton 
belum mencapai tuntas belajar dengan nilai ketuntasan 75 dalam ranah kognitif seperti terlihat dalam Tabel 1

Tabel 1 Rerata Penilaian Harian KD Hukum Newton

Kelas X Semester II Tahun pelajaran 2017/2018

\begin{tabular}{|c|c|}
\hline Kelas & Rerata \\
\hline X IPA 1 & 62,11 \\
\hline X IPA 2 & 61,94 \\
\hline X IPA 3 & 61,83 \\
\hline X IPA 4 & 61,25 \\
\hline
\end{tabular}

Dari tabel tersebut menunjukkan hahwa peseretasi belajar mata pelajaran fisika untuk KD Hukum Newton belum memenuhi apa yang diharapkan. Rendahnya hasil belajar Fisika SMA Negeri 85 Jakarta menunjukan rendahnya pemahaman peserta didik terhadap konsep Fisika bila ditinjau dari penyebabnya bisa disebabkan oleh faktor internal dan eksternal dari peserta didik, juga dari guru; salah satunya dalam penggunaan metode pembelajaran yang kurang bervariasi yang membangun keaktifan peserta didik, sehingga SMA Negeri 85 Jakarta perlu melakukan upaya tertentu untuk mengoptimalkan pembelajaran Fisika untuk meningkatkan hasil belajar dan keaktifan peserta didik.

Penyelenggaraan kegiatan pembelajaran diperlukan konsep, model dan metode pembelajaran Afandi (2013: 16) didefinisikan bahwa "Model pembelajaran adalah prosedur atau pola sistematis yang digunakan sebagai pedoman untuk mencapai tujuan pembelajaran didalamnya terdapat strategi, teknik, metode, bahan, media, dan alat penilaian. Sedangkan metode pembelajaran adalah cara atau tahapan yang digunakan dalam interaksi antara peserta didik dan pendidik untuk mencapai tujuan pembelajaran yang telah ditetapkan sesuai dengan materi dan mekanisme metode pembelajaran".

Untuk keperluan itu perlu adanya terobosan dalam pembelajaran Fisika sehingga tidak sekedar menyajikan angka-angka tetapi harus melibatkan peserta didik secara langsung dalam pembelajaran, sehingga pembelajaran yang dilakukan harus menggunakan metode yang sesuai dengan mempermudah pemahaman peserta didik yang akhirnya akan mengubah anggapan peserta didik dari sulit menjadi mudah.

Fisika sebagai ilmu dasar memiliki karakteristik yang mencakup bangun ilmu yang terdiri atas fakta, konsep, prinsip, hukum, postulat dan teori serta metodologi keilmuan. Fisika dalam mengkaji obyek-obyek telaah yang berupa benda-benda serta peristiwa alam menggunakan prosedur yang baku yang disebut metode/proses ilmiah. Mundilarto (2010:3) menyatakan bahwa "Fisika merupakan ilmu yang berusaha memahami aturan-aturan alam yang begitu indah dan dengan rapih dapat dideskripsikan secara matematis"

Untuk mendapatkan hasil belajar fisika yang baik diperlukan langkah awal penunjang keberhasilan belajar di kelas sebagai langkah awal penunjang keberhasilan belajar fisika. Pada umumnya peserta didik belajar fisika di kelas tanpa melakukan persiapan sebelumnya, sehingga kemampuan awal peserta didik terbatas. Hal ini mengakibatkan informasi yang diberikan guru tidak dengan cepat diterima peserta didik. Sehingga guru perlu mengulang informasi tersebut sampai peserta didik dapat menerimanya. Oleh sebab itu, maka guru harus mampu mengendalikan kemampuan awal peserta didiknya.

Pembelajaran fisika dengan berbagai metode pembelajaran diperkenalkan dan diterapkan di sekolahsekolah. Menurut Rusyan (2012: 87) pertimbangan pemilihan metode pembelajaran bertolak pada faktorfaktor berikut:

1. Berpedoman pada tujuan yang hendak dicapai dalam setiap interaksi edukatif

2. Perbedaan individual peserta didik; aspek biologis, intelektual, dan psikologis.

Pengembangan metode pembelajaran initerus dilakukan dan dikembangkan Prihantini (2017: 173) dalam jurnalnya mengatakan metode pembelajaran adalah "cara yang dipergunakan guru dalam mengadakan hubungan dengan peserta didik pada saat berlangsungnya pengajaran disesuaikan dengan kebutuhan dan pokok bahasan yang diajarkan". Pemilihan metode dan pendekatan yang mengaktifkan peserta didik diantaranya ialah metode discovery, inquiry, eksperimen, pemecahan masalah, keterampilan proses, penugasan, dandiskusi (R. Ibrahim, 2003: 20).

Tuntutan yang tercantum dalam kurikulum pelajaran fisika untuk KD Hukum Newton adalah menganalisis interaksi gaya serta hubungan antara gaya, massa, dan gerakan benda pada gerak lurus (Dokumen 2 KTSP SMAN 85, 2018: 14 ). KD ini sangat berkaitan erat dengan kehidupan sehari-hari 
peserta didik untuk memenuhi tuntutan tersebut diperlukan metode pembelajaran yang mendorong peserta didik berpartisipasi aktif dalam kegiatan belajar mengajar di kelas. Menurut Ardi (2013: 25) metode inquiry learning merupakan metode pembelajaran yang berupaya menanamkan dasar-dasar berpikir ilmiah pada diri peserta didik, sehingga dalam proses pembelajaran ini peserta didik lebih banyak belajar sendiri, mengembangkan kreatifitas dan memecahkan masalah peserta didik. Peserta benar-benar ditempatkan sebagai subyek belajar, peran guru dalam pembelajaran dengan metode inquiry learning adalah sebagai pembimbing dan fasilitator.

Berdasarkan uraian di atas penulis bermaksud melakukan studi penelitian lebih lanjut apakah terdapat pengaruh metode pembelajaran inquiry pictorial riddle dibandingkan menggunakan inquiry learning terhadap hasil belajar fisika konsep hukum Newton pada peserta didik kelas X jurusan IPA SMA Negeri 85 Jakarta.

\section{METODE PENELITIAN}

Jenis penelitian yang digunakan pada penelitian ini (quasi experimental design). Penelitian ini menggunakan pendekatan ANAKOVA. Menurut Supardi (2011: 390) penelitian dengan pendekatan ANAKOVA adalah sebuah penelitian eksperimen yang membandingkan antara hasil post-test pada kelompok eksperimen dengan kelompok kontrol, setelah mengendalikan pengaruh pre-test (kemampuan awal).

Analisa kovarian yang melibatkan satu variabel kovariant (X) disebut ANAKOVA sederhana, karena dalam permasalahannya hanya melibatkan regresi linier sederhana $\hat{Y}=a+b X$. Sedangkan jika dalam analisis kovarian tersebut hanya melibatkan satu variabel bebas katagorik/treatment maka disebut ANAKOVA satu jalur. Jadi ANAKOVA sederhana satu jalur yaitu ANAKOVA dengan satu variabel bebas kovariant $(\mathrm{X})$, variabel bebas katagorik/treatment $(\mathrm{A})$, dan satu variabel tergantung/kriteria (Y).

\section{HASIL DAN PEMBAHASAN}

Berdasarkan hasil penelitian yang telah dilaksanakan, diperoleh data penelitian yang dioleh menggunakan program Microsoft Excel 2007. Berikut ini disajikan rangkuman analisis datanya

Tabel 6 Deskripsi Data Hasil Penelitian

\begin{tabular}{|c|c|c|c|c|c|}
\hline \multicolumn{2}{|c|}{$\overline{\mathbf{A}_{1}}$} & \multicolumn{2}{|c|}{$\mathbf{A}_{2}$} & \multicolumn{2}{|c|}{$\sum$ Total } \\
\hline $\mathrm{X}_{1}$ & $Y_{1}$ & $\mathbf{X}_{2}$ & $\mathbf{Y}_{2}$ & $\sum \mathbf{X}$ & $\sum \mathbf{Y}$ \\
\hline \multicolumn{2}{|c|}{$n=36$} & \multicolumn{2}{|c|}{$\mathrm{n}=36$} & \multicolumn{2}{|c|}{$\mathrm{n}=72$} \\
\hline$\sum X_{1}=21089$ & $\sum \mathbf{Y}_{1}=27459$ & $\sum X_{2}=19793$ & $\sum Y_{2}=22340$ & $\sum X=40882$ & $\sum Y=49799$ \\
\hline$\ddot{\mathrm{X}}_{1}=585,81$ & $\overline{\bar{Y}}_{1}=769,25$ & $\ddot{X}_{2}=549,81$ & $\overline{\mathbf{Y}}_{2}=620,56$ & $\ddot{\ddot{X}}=567,81$ & $\overline{\bar{Y}}=694,90$ \\
\hline
\end{tabular}

Keterangan:

$\mathrm{A}_{1} \quad$ : Kegiatan perlakuan/treatment pada kelompok eksperimen (metode inquiry pictorial riddle)

$\mathrm{A}_{2} \quad$ : Kegiatan perlakuan/treatment pada kelompok kontrol (metodeinquiry learning)

$\mathrm{X}_{1} \mathrm{X}_{2} \quad$ : Observasi variabel kovariant (nilai pre-test) yaitu kemampuan awal

$\mathrm{Y}_{1} \mathrm{Y}_{2}$ : Observasi variabel kriteria (post-test) yaitu hasil belajar fisika

Data skor kemampuan awal kelompok eksperimen diperoleh dengan penilaian pre-test kelas eksperimen (X IPA2). Dalam kelas eksperimen dianalisis kemampuan awalnya terdapat 36 peserta didik, dengan statistik nilai sebagai berikut:

Tabel 7 Distribusi Frekuensi Skor Kemampuan Awal (Pre-Test) Kelompok Eksperimen

\begin{tabular}{|l|l|l|l|l|l|l|l|l|}
\hline No & Skor & $\mathbf{f i}$ & $\mathbf{F i}$ & $\mathbf{X i}$ & $\mathbf{f i X i}$ & $\left.\mathbf{( X i -}^{-}\right)^{\mathbf{2}}$ & $\mathbf{f i ( X i - \ddot { X } ) ^ { 2 }}$ & $\mathbf{f i} \%$ \\
\hline 1 & $380-447$ & 1 & 1 & 414 & 414 & 29518,68 & 29518,68 & 2,78 \\
\hline 2 & $448-515$ & 7 & 8 & 482 & 3374 & 10776,52 & 75435,61 & 19,44 \\
\hline 3 & $516-583$ & 8 & 16 & 550 & 4400 & 1282,356 & 10258,85 & 22,22 \\
\hline 4 & $584-651$ & 13 & 29 & 618 & 8034 & 1036,196 & 13470,55 & 36,11 \\
\hline
\end{tabular}




\begin{tabular}{|c|c|c|c|c|c|c|c|c|}
\hline No & Skor & $\mathrm{fi}$ & $\mathbf{F i}$ & $\mathbf{X i}$ & fiXi & $(\mathrm{Xi}-\ddot{\mathrm{X}})^{2}$ & $\mathrm{fi}(\mathrm{Xi}-\ddot{\mathrm{X}})^{2}$ & fi $\%$ \\
\hline 5 & $652-719$ & 3 & 32 & 686 & 2058 & 10038,04 & 30114,11 & 8,33 \\
\hline 6 & $720-787$ & 4 & 36 & 754 & 3016 & 28287,88 & 113151,5 & 11,11 \\
\hline \multicolumn{2}{|c|}{ Jumlah } & 36 & & & 21296 & 80939,66 & 271949,3 & \\
\hline
\end{tabular}

Histogram dan Poligon

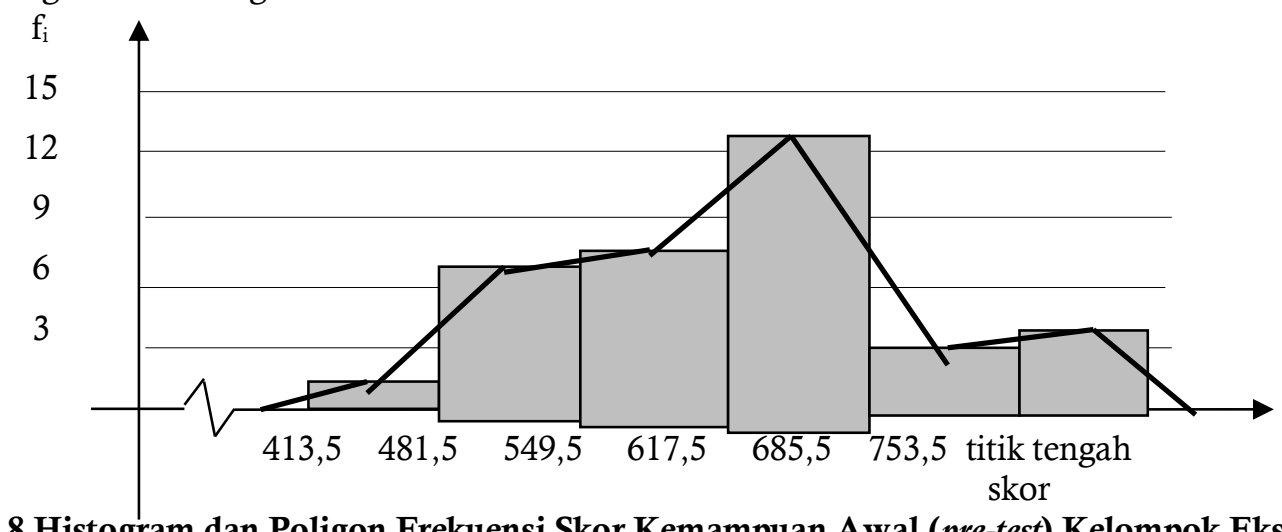

Gambar 8 Histogram dan Poligon Frekuensi Skor Kemampuan Awal (pre-test) Kelompok Eksperimen

Berdasarkan hasil analisis data di atas diperoleh skor rata-rata untuk skor kemampuan awal kelompok eksperimen sebesar 58,58. Kondisi ini menunjukan bahwa kemampuan awal kelompok eksperimen dengan di atas KKM yakni sebesar 75 berjumlah $2(5,56 \%)$ peserta didik, hasil belajar ini tergolong rendah sedangkan nilai peserta didik berada di bawah KKM berjumlah $34(94,44 \%)$ peserta didik. Sementara nilai median dan modusnya masing-masing sebesar 52,60 dan 60,62 dengan standar deviasi 88,15. Dari rata-rata menunjukkan perbedaan jawaban antar responden tidak banyak beragam.

Dengan mengontrol/mengendalikan pengaruh kemampuan awal (X), ada perbedaan hasil belajar fisika $(\mathrm{Y})$ peserta didik yang belajar menggunakan metode inquiry pictorial riddle dengan menggunakan metode inquiry learning. Hasil pengujian hipotesis maineffect diperolah hasil Fhitung $>$ Ftabel $(34,50>$ 4,13), maka H0 ditolak, dan disimpulkan terdapat perbedaan hasil belajar fisika (Y) yang signifikan antara peserta didik yang menggunakan metode inquiry pictorial riddle (Y1) dan metode inquiry learning (Y2), setelah mengontrol pengaruh kemampuan awal (X) peserta didik. Hal ini menunjukkan bahwa dengan mengontrol/mengendalikan pengaruh kemampuan awal peserta didik terdapat pengaruh penggunaan metode inquiry pictorial riddle terhadap hasil belajar fisika. Ini ditunjukan dengan rata-rata hasil belajar fisika antara kolompok eksperimen dan kelompok kontrol yang berbeda, yaitu 76,93 dan 62,06. Hal tersebut disebabkan oleh beberapa keterbatasan penelitian:

a. Keterbatasan waktu dan prasarana pendukung pada treatment metode inquiry pictoril riddle terhadap kelas eksperimen, sehingga hasil belajar kurang maksimal.

b. Pemilihan materi Hukum Newton cukup sulit untuk disajikan dengan metode inquiry pictorial riddle.

Karena $t_{\text {hitung }}>t_{\text {tabel }}(3,61<3,88)$ maka diterima $H_{0}$. Dengan demikian disimpulkan bahwa dengan mengendalikan pengaruh kemampuan awal (X), secara signifikan hasil belajar fisika $(\mathrm{Y})$ peserta didik yang belajar menggunakan metode inquiry pictorial riddle (Y1) lebih besar daripada yang belajar menggunakan metode inquiry learning (Y2)

\section{PENUTUP}

Berdasarkan hasil penelitian dapat disimpulkan: Dengan mengontrol/mengendalikan kemampuan awal $(\mathrm{X})$ terdapat perbedaan hasil belajar fisika $(\mathrm{Y})$ yang signifikan antara peserta didik yang belajar menggunakan metodeinquiry pictorial riddledengan yang menggunakan metode inquiry learning. Hal ini dibuktikan dengan nilai $F_{\text {hitung }}<F_{\text {tabel }}(34,50>4,13)$ dengan tingkat signifikansi $5 \%$. Dengan mengontrol/mengendalikan kemampuan awal $(\mathrm{X})$ hasil belajar fisika $(\mathrm{Y})$ peserta didik yang belajar 
menggunakan metode inquiry pictorial riddlelebih tinggi dari pada yang menggunakan metode inquiry learning. Hal ini dibuktikan dengan nilai $t_{\text {hitung }}>t_{\text {tabel }}(3,61<3,88)$.

\section{DAFTAR PUSTAKA}

Afandi, Muhamad. Dkk. (2013). Model dan Metode Pembelajaran Di Sekolah. Semarang: Unissula Press.

Anjani, Yullida Ferry. (2017). Analisis Kemampuan Berpikir Tingkat Tinggi Menurut Teori Anderson dan Karthwohl Pada Peserta Didik kelas XI Bilingual Class System MAN 2 Kudus Pada Pokok Bahasan Program Linier. UIN Walisongo Semarang: 2017) skripsi

Arantika, Jane. Dkk. (2014). Pengaruh inkuiri Berbentuk Pictorial Riddle terhadap Kemampuan Berpikir Kritis Pada Materi Koloid di SMA.jurnal.untan.ac.id

Ardi, Bahrudin. (2013). Penerapan Metode Inquiry Untuk Meningkatkan Kualitas Pembelajaran IPA Pada Siswa Kelas V SDN 5 Mayong Lor Kabupaten Jepara. https://lib.unnes.ac.id/18238/1/1402908125

Budiyono. (2018)."Pengantar Penilaian Hasil Belajar". Solo: UNS Press

Burhanudin, Afif. (2014). Teori Belajar. https://afidburhanuddin.wordpress.com

Chusni, Mainan, M. Dkk. (2016). Penerapan Pendekatan Inquiry Terbimbing dengan Metode Pictorial Riddle Untuk Meningkatkan Pemahaman Konsep Fisika Siswa. Ojs.fkip.ummetro.ac.id

Dewati, Maria. (2012). Pengaruh Metode Belajar dan Tingkat Penalaran Formal Terhadap Hasil Belajar Fisika SMA. www.nekti.cm/publication/234937/

Duwi. (2011). Uji Homogenitas. 27 November 2011. Duwiconsultant,blogspot.com

Dwiradyan, Bagus. (2014). Kerucut Pengalaman Belajar. Wordpress.com

Febriana, Maghfira dkk. (2018). Penerapan Model Pembelajaran Inquiry Pictorial Riddle Untuk Meningkatkan Keaktifan Siswa. http://e-journal.unipma.ac.id

Gantini, Pipit. (2017). Penilaian Hasil Belajar. Jakarta: Esensi

Hanifah, Nani dkk. (2014). Perbandingan Tingkat Kesukaran, Daya Pembeda Butir soal, dan Reliabilitas Tes. https//.journal.lppm unindra.ac.id

Imelda. dkk. (2013). Pengembangan Perangkat pembelajaran IPA Fisika Melalui Model Pembelajaran Inquiry dengan metode pictorial riddle. https://ppjp.ulm.ac.id

Jihad dan Abdul, H .(2010). Evaluasi Pembelajaran. Jakarta: Multi Press.

Kamajaya, Ketut. (2016). Aktif dan Kreatif Belajar Fisika. Bandung: Grafindo Media Pratama.

Kuswiandi, Wendy. (2013). Faktor yang Mempengaruhi Belajar. 4 Maret 2019. whendikz.blogspot.com/2013/10/.

Mulyana, Aina. (2015). Mengenal Berbagai Jenis Teori Belajar. 4 Maret 2019. https://ainamulyana.blogspot.com

Mundilarto. (2010)."Penilaian Hasil Belajar Fisika". Yogyakarta: Pusat Pengembangan Instruksional Sains.

Nurhasanah, Siti. Dkk (2016). Minat Belajar Sebagai Determinan Hasil Belajar Siswa. ejournal.upi.edu/index.php/jpmamper/articel/32412338 journal

Nurpratiwi, Rahma Tisa. Dkk. (2015). Peningkatan Aktivitas dan Prestasi Belajar Siswa Melalui Metode Picture and Picture Dengan Media Audio Visual Pda Mata Pelajaran Geografi Di Kelas XI IPS@ SMA Negeri 1 Bantar Kawung. https://media.neliti.com/media/publication/55632

Prihantini, Effiyati. dkk. (2017). Pengaruh Metode Pembelajaran dan Minat Belajar Terhadap Hasil Belajar IPA. Journal Formatis.

Pujianto, Agus. Dkk. (2017). Pembelajaran Inkuiri Untuk meningkatkan Kemampuan Berpikir Kritis dan Prestasi Belajar IPS.Journal.fkip.unila.ac.id

Purwanto, Ngalim. (2010). Prinsip-prinsip dan teknik evaluasai pembelajaran. Bandung: Remaja Rosdakarya.

Roida. Dkk. (2012). Metode Pembelajaran Inkuiri dan Pengaruhnya Terhadap Hasil Belajar Matematika Ditinjau dari Kreativitas Belajar. journal.lppm unindra.ac.id.

Rusyan, Tabrani. H.A. (2012). Membangun Guru Berkualitas. Jakarta: PT. Pustaka Dinamika.

Sanjaya, W (2010). Strategi Pembelajaran Berorientasi Standar Pendidikan. Jakarta: Kencana.

Sugiarti, E. dkk. (2015). Pengaruh Model Pembelajaran Berbasis Metode Pictorial Riddle Terhadap Kemampuan Berkomunikasi Ilmiah Siswa SMP. http://journalunnes.ac.id.

Sugiyono (2010). "Statistik Untuk Penelitian". Bandung: Alfa Beta. 
Sumiyarsih, Nur, A. (2017)' Tiga Jenis Teori Belajar. 6 Maret 2019, https://nursbio.wordpress.com.

Supardi U.S. 2011. Aplikasi Statistika dalam Penelitian. Jakarta: Ufuk Press.

Supardi U.S. 2013. Aplikasi Statistika dalam Penelitian. Jakarta: Change Publication

Susanto, Hadi. (2017).Teori Belajar. 5 Maret 2019. https://bagawan abiyasa.wordpress.com.

Susilawati. Dkk. (2015), Perbandingan Hasil Belajar Fisika Antara Metode Pictorial Riddle dengan Metode Demonstrasi dalam Pembelajaran Inkuiri Terbimbing Pada Siswa Kelas VIII SMPN 19 Palu. journal untad.ac.id.

Suyatno. (2013). Menjadi Guru Profesional. Jakarta: Esensi.

Tabrani. (2017). Empat Pilar Pendidikan Sepanjang Hayat. 20 Februari 2019. www.tabraniza.com.

Thohir, Anas. (2018). Kesulitan Belajar dan Cara Mengatasinya. Jakarta: Media Press.

Wibowo, Dwi Cahyadi. (2013). Taksonomi Anderson. 24 Februari 2013. dwicahyadiwibowo.blogspot.com.

Winataputra, Udin. S. Hakikat Belajar dan Pembelajaran, repository ut.ac.id/4035/1/MK DK 4004M1.pdf.

Yunita. Dkk. (2016). Perbedaan Hasil Keterampilan Proses Sains Melalui Model Pembelajaran Inquiry dan Model Pembelajaran dengan metode Pictorial Riddle Bagi Siswa SMPN I Guning Sari Tahun Ajaran 2015/2016. jurnal. fkip.unram.ac.id. 